\title{
Predicting acute uncomplicated urinary tract infection in women: a systematic review of the diagnostic accuracy of symptoms and signs
}

\author{
Leonie GM Giesen ${ }^{1,2 *}$, Gráinne Cousins ${ }^{1}$, Borislav D Dimitrov ${ }^{1}$, Floris A van de Laar ${ }^{2}$, Tom Fahey ${ }^{1}$
}

\begin{abstract}
Background: Acute urinary tract infections (UTI) are one of the most common bacterial infections among women presenting to primary care. However, there is a lack of consensus regarding the optimal reference standard threshold for diagnosing UTI. The objective of this systematic review is to determine the diagnostic accuracy of symptoms and signs in women presenting with suspected UTI, across three different reference standards $\left(10^{2}\right.$ or $10^{3}$ or $10^{5} \mathrm{CFU} / \mathrm{ml}$ ). We also examine the diagnostic value of individual symptoms and signs combined with dipstick test results in terms of clinical decision making.
\end{abstract}

Methods: Searches were performed through PubMed (1966 to April 2010), EMBASE (1973 to April 2010), Cochrane library (1973 to April 2010), Google scholar and reference checking.

Studies that assessed the diagnostic accuracy of symptoms and signs of an uncomplicated UTI using a urine culture from a clean-catch or catherised urine specimen as the reference standard, with a reference standard of at least $\geq 10^{2} \mathrm{CFU} / \mathrm{ml}$ were included. Synthesised data from a high quality systematic review were used regarding dipstick results. Studies were combined using a bivariate random effects model.

Results: Sixteen studies incorporating 3,711 patients are included. The weighted prior probability of UTI varies across diagnostic threshold, $65.1 \%$ at $\geq 10^{2} \mathrm{CFU} / \mathrm{ml} ; 55.4 \%$ at $\geq 10^{3} \mathrm{CFU} / \mathrm{ml}$ and $44.8 \%$ at $\geq 10^{2} \mathrm{CFU} / \mathrm{ml} \geq 10^{5} \mathrm{CFU} / \mathrm{ml}$. Six symptoms are identified as useful diagnostic symptoms when a threshold of $\geq 10^{2} \mathrm{CFU} / \mathrm{ml}$ is the reference standard. Presence of dysuria (+LR $1.3095 \% \mathrm{Cl} 1.20-1.41$ ), frequency (+LR $1.1095 \% \mathrm{Cl} 1.04-1.16)$, hematuria (+LR 1.72 95\%Cl 1.30-2.27), nocturia (+LR $1.3095 \% \mathrm{Cl} 1.08-1.56$ ) and urgency (+LR $1.2295 \% \mathrm{Cl} 1.11-1.34$ ) all increase the probability of UTI. The presence of vaginal discharge (+LR $0.6595 \% \mathrm{Cl} 0.51-0.83)$ decreases the probability of UTI. Presence of hematuria has the highest diagnostic utility, raising the post-test probability of UTI to $75.8 \%$ at $\geq 10^{2} \mathrm{CFU} / \mathrm{ml}$ and $67.4 \%$ at $\geq 10^{3} \mathrm{CFU} / \mathrm{ml}$. Probability of UTI increases to $93.3 \%$ and $90.1 \%$ at $\geq 10^{2} \mathrm{CFU} / \mathrm{ml}$ and $\geq 10^{3} \mathrm{CFU} / \mathrm{ml}$ respectively when presence of hematuria is combined with a positive dipstick result for nitrites. Subgroup analysis shows improved diagnostic accuracy using lower reference standards $\geq 10^{2} \mathrm{CFU} / \mathrm{ml}$ and $\geq 10^{3} \mathrm{CFU} / \mathrm{ml}$.

Conclusions: Individual symptoms and signs have a modest ability to raise the pretest-risk of UTI. Diagnostic accuracy improves considerably when combined with dipstick tests particularly tests for nitrites.

\section{Background}

Acute uncomplicated urinary tract infections (UTI) are one of the most common bacterial infections among women presenting to primary care, with an annual incidence of $7 \%$ for all ages of women peaking at $15-24$ years

\footnotetext{
* Correspondence: leonie.giesen@student.ru.nl

'HRB Centre for Primary Care Research, Department of General Practice, Royal College of Surgeons in Ireland, Beaux Lane House, Lower Mercer Street, Dublin 2, Ireland

Full list of author information is available at the end of the article
}

and women older than 65 [1]. Approximately one third of all women have had at least one physician-diagnosed uncomplicated UTI by the age of 26 years [2].

The original reference standard for diagnosing UTI was the presence of significant bacteriuria, defined as the isolation of at least $10^{5}$ colony-forming units (CFU) of a single uropathogen, in a clean catch or catherised urine specimen [3]. However, this cut-off limit has been debated in recent years resulting in the use of reduced

\section{Biomed Central}


diagnostic thresholds ranging from $10^{2}$ [4-7] and $10^{3}$ [8-11].

The pre-test probability of asymptomatic bacteriuria in women of reproductive age is approximately $5 \%[12,13]$. However, the pre-test probability of an uncomplicated UTI is shown to increase from $5 \%$ to $50 \%$ among women presenting with at least one symptom of an uncomplicated UTI [14]. Symptoms of an uncomplicated UTI include dysuria (painful voiding), frequency (frequent voiding of urine), urgency (the urge to void immediately), and hematuria (presence of blood in urine). In contrast, patients presenting with vaginal discharge or irritation have a decreased risk of an uncomplicated UTI [14]. The presence or absence of symptoms function as useful diagnostic tests. Near patient testing in the form of urinary dipsticks are also commonly used in Primary Care to improve the precision of UTI diagnosis, providing immediate results which can be interpreted alongside patient symptoms.

Although empirical treatment of UTI is most costeffective $[15,16]$, prescribing without confirmation of diagnosis contributes to the growing problem of resistance against uropathogens in primary care [17].

A previous systematic review established the diagnostic accuracy of symptoms and signs for UTI [14], however, it remains unclear whether the diagnostic accuracy of symptoms and signs varies when alternative reference standards are applied. The aim of this systematic review is to determine the diagnostic accuracy of symptoms and signs of UTI in adult women across three different reference standards, $10^{2}, 10^{3}$ and $10^{5} \mathrm{CFU} / \mathrm{ml}$. In addition, we aim to determine the diagnostic accuracy of symptoms and signs combined with dipstick test results.

\section{Methods}

The PRISMA guidelines for reporting on systematic reviews and meta-analysis were followed to conduct this review (Additional file 1).

\section{Search strategy}

We performed a systematic search of three online databases, Pubmed (1966 to April 2010), Embase (1973 to April 2010) and the Cochrane Library (1973 to April 2010). A combination of MeSH terms and text words were used including: 'urinary tract infection/pyelonephritis/cystitis/urethritis', 'physical examination/medical history taking/professional competence', 'sensitivity and specificity', ' reproducibility of results/diagnostic tests, routine/decision support techniques/bayes theorem/predictive value of tests'. All combinations were restricted to 'women and female'. This search was supplemented by checking references of filtered papers and searching Google Scholar [18]. No restrictions were placed on language.

\section{Study selection}

To be eligible for inclusion, the studies had to fulfil the following criteria:

1) Have a study population of adult symptomatic women with suspected uncomplicated UTI presenting to a primary care setting.

2) Use a cohort or cross-sectional study design. Case control studies were excluded.

3) Investigate the diagnostic accuracy of symptoms and signs of UTI using a urine culture from a cleancatch or catherised urine specimen as the reference test, with a diagnostic threshold of at least $\geq 10^{2}$ $\mathrm{CFU} / \mathrm{ml}$.

4) Include sufficient data to allow for the calculation of sensitivity, specificity, negative and positive predictive values and the prevalence of uncomplicated UTI.

\section{Data extraction}

The number of true positives, false positives, true negatives and false negatives for each sign and symptom were extracted from each of the studies and a $2 \times 2$ table was constructed. Discrepancies were resolved by discussion between the two reviewers (LG and GC). Authors were contacted to provide further information when there was insufficient detail in an article to construct a $2 \times 2$ table.

\section{Quality assessment}

The methodological quality of the selected studies was evaluated independently by two reviewers (LG and GC) using the Quality Assessment of Diagnostic Accuracy Studies (QUADAS) tool, a validated tool for the quality assessment of diagnostic accuracy studies [19]. This tool was modified to ensure appropriateness to the present study and included twelve questions from the QUADAS tool with two additional questions extracted from a different review [20]. If no consensus was achieved, studies were evaluated by a third independent reviewer (TF).

\section{Data synthesis and analysis}

\section{Summary estimates across different reference standards}

We used the bivariate random effects model to estimate summary estimates of sensitivity and specificity and their corresponding 95\% confidence intervals. This approach was used as it preserves the two-dimensional nature of the original data and takes into account both study size and heterogeneity beyond chance between studies [21]. In addition, the bivariate model estimates and incorporates the negative correlation which may arise between the sensitivity and specificity of a given sign or symptom as a result of differences in reference 
standards used in different studies. These alternative thresholds are important when attempting to understand the diagnostic accuracy of symptoms and signs predicting uncomplicated UTI as studies have used different thresholds ranging from $\geq 10^{2} \mathrm{CFU} / \mathrm{ml}, \geq 10^{3}$ $\mathrm{CFU} / \mathrm{ml}$ and $\geq 10^{5} \mathrm{CFU} / \mathrm{ml}$. However, pooled estimates cannot be calculated using the bivariate model with less than 4 studies.

We plotted the individual and summary estimates of sensitivity and specificity for each symptom and sign at the different threshold levels in a receiver operating characteristic graph, plotting a symptom's sensitivity (true positive) on the $y$ axis against 1-specificity (false negative) on the $x$ axis. We also plotted the $95 \%$ confidence region and $95 \%$ prediction region around the pooled estimates to illustrate the precision with which the pooled values were estimated (confidence ellipse around the mean value) and to illustrate the amount of between study variation (prediction ellipse). We assessed heterogeneity visually using the summary ROC plots and statistically by using the variance of logit transformed sensitivity and specificity, with smaller values indicating less heterogeneity among studies.

\section{Bayesian analysis and near patient testing (dipstick)}

To examine the influence of threshold effects when considering alternative reference standards we conducted subgroup analysis across the three different thresholds: $\geq 10^{2} \mathrm{CFU} / \mathrm{ml}, \geq 10^{3} \mathrm{CFU} / \mathrm{ml}$ and $\geq 10^{5} \mathrm{CFU} / \mathrm{ml}$. Using Bayes theorem the post-test odds of a UTI were estimated by multiplying the pretest odds by the likelihood ratio, where pre-test odds is calculated by dividing the pre-test probability by (1-pre-test probability) and the post-test probability equals post-test odds divided by $(1+$ post-test odds) [22]. Finally, the diagnostic accuracy of individual symptoms and signs combined with dipstick test results for nitrites, leucocyte-esterase and combined nitrites and leucocyte-esterase, was determined using data synthesised in a previous high quality systematic review regarding the diagnostic accuracy of dipstick urinalysis [23].

We used Stata version 10.1(StataCorp, College Station, Tx, USA), particularly the metandi commands, for all statistical analyses

\section{Results}

\section{Search Strategy}

Two researchers (LG, GC) screened all potential articles and agreed that the full text of 51 articles should be examined. Nineteen relevant studies were identified by our search strategy [4,6-10,24-36]. Five additional studies [37-41] were found by citation searching and two studies by Google Scholar [42,43]. Ten of the 26 studies reported all required data [8-10,25,37-42]. The authors of the remaining papers were contacted for additional data. Ten authors responded [4,6,7,24,26-28,32,35,43,44] and six studies were subsequently included $[4,6,7,24,26,43]$. The flow diagram of our search strategy is presented in Figure 1.

\section{Characteristics of included studies}

The sixteen studies included 3,711 patients and were carried out in a primary care setting. One study was based in the USA [39], two in Canada [4,6], one in New Zealand [38], eight in the UK $[8,9,24,25,37,40,41,43]$ and four in other European countries $[7,10,26,42]$. The mean weighted prior probability is 65.1 using a reference test of $\geq 10^{2} \mathrm{CFU} / \mathrm{ml}$. The mean weighted prior probability using a reference test of $\geq 10^{3} \mathrm{CFU} / \mathrm{ml}$ and $\geq 10^{5} \mathrm{CFU} /$ $\mathrm{ml}$ is $55.4 \%$ and $44.8 \%$ respectively. Summary characteristics of each included study are presented in Table 1.

\section{Quality assessment}

The summary diagram of the quality assessment is shown in Figure 2. The overall quality of the included studies ranges from moderate to good. It is important to note that several studies were conducted before the introduction of standards for reporting diagnostic accuracy studies [37-41]. Spectrum bias is identified as a potential source of bias across certain studies, with studies including both complicated and uncomplicated patients $[7,38]$ or failing to clearly report whether the study was focusing on complicated or uncomplicated UTI $[26,40]$. Partial verification bias is also noted in two studies whereby only a selected sample of patients' symptoms are verified by the reference test $[24,41]$. Furthermore, the presence of un-interpretable test results and blinding of symptoms and signs and reference test results are poorly reported.

\section{Diagnostic test accuracy of symptoms and signs Summary estimates across different reference standard thresholds}

Sixteen studies examined the accuracy of ten different symptoms and signs of UTI. The pooled sensitivities, specificities and the respective variance of the logittransformed sensitivity and specificity, for individual symptoms and signs at each of the three reference standard threshold levels are presented in Tables 2, 3 and 4 respectively. Furthermore, the summary estimates of positive and negative likelihood ratio's for individual symptoms and signs at each of the three threshold levels are presented in Table 5. Six symptoms are identified as having useful diagnostic value at a reference standard threshold of $\geq 10^{2} \mathrm{CFU} / \mathrm{ml}$, as their $95 \%$ confidence interval values do not cross the line of no effect. Presence of dysuria, frequency, hematuria, nocturia and urgency are found to increase the probability of UTI. Presence of vaginal discharge decreases the probability 


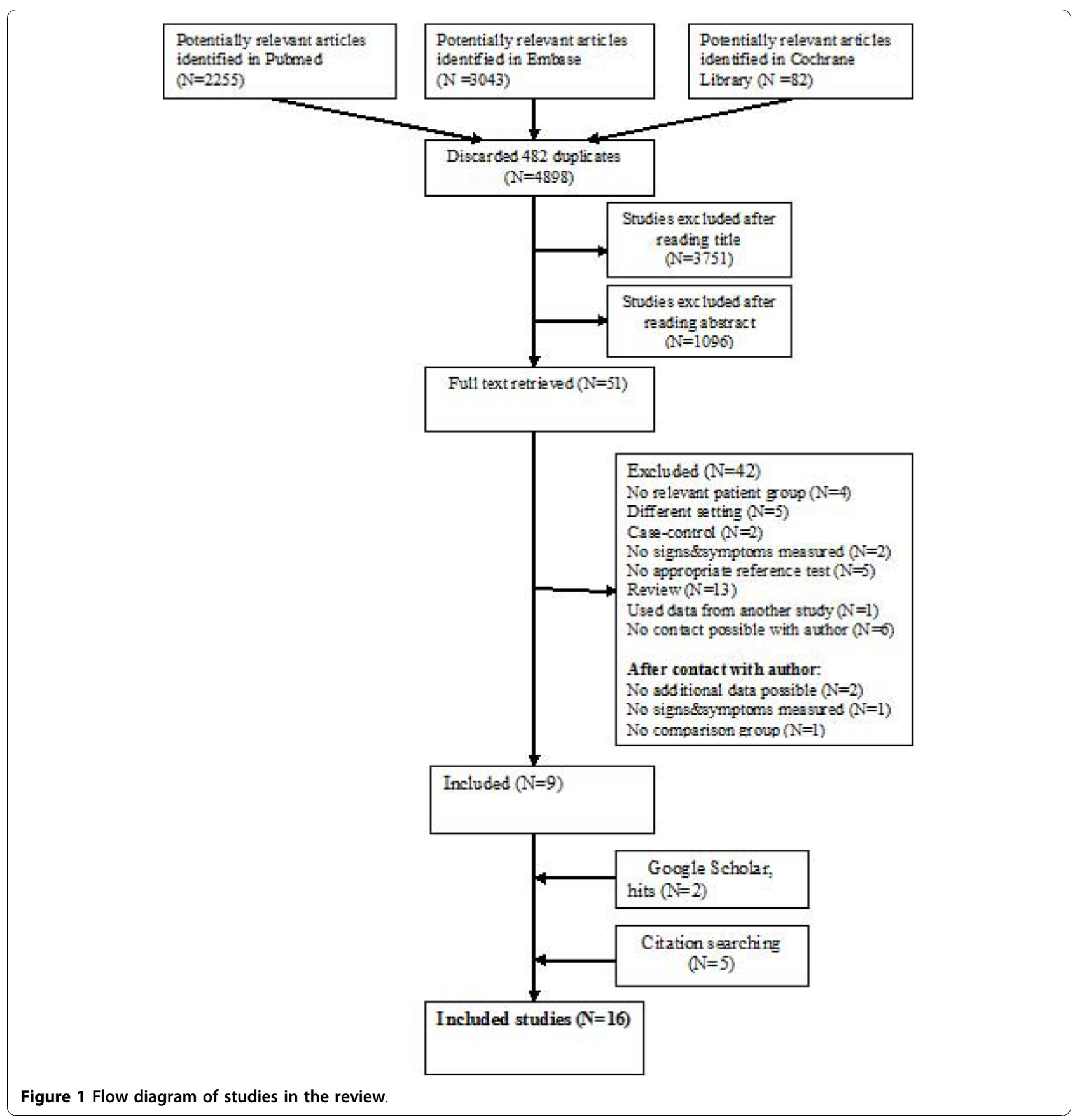

of UTI. Presence of hematuria in urine has the highest diagnostic utility $(L R+1.72)$, with a specificity of 0.85 and a sensitivity of 0.25 , thus hematuria when present is more useful in 'ruling in' UTI. In contrast, all other significant symptoms are identified as being more useful in 'ruling out'. A similar pattern of results emerge using a higher reference standard threshold $\geq 10^{3} \mathrm{CFU} / \mathrm{ml}$. Consistent with lower threshold effects dysuria, frequency and urgency remain significant symptoms for ruling out a urinary tract infection at $\geq 10^{5} \mathrm{CFU} / \mathrm{ml}$.
The individual and summary estimates of sensitivity and specificity, the $95 \%$ confidence region and $95 \%$ prediction region for each symptom and sign at each of the threshold levels are presented in a receiver operating characteristic graph in figures 3, 4 and 5. The 95\% confidence region remains large for several symptoms and signs across the different diagnostic thresholds, with the exception of dysuria, frequency and hematuria. This indicates greater precision of the pooled estimates for dysuria, frequency and hematuria. The $95 \%$ prediction 
Table 1 Summary of included studies

\begin{tabular}{|c|c|c|c|c|c|c|}
\hline Study & Inclusion criteria & $\begin{array}{l}\text { No. of } \\
\text { patients }\end{array}$ & $\begin{array}{l}\text { Mean age, y } \\
\text { (range) }\end{array}$ & $\begin{array}{l}\text { Incidence } \\
\text { of UTI\% }\end{array}$ & $\begin{array}{l}\text { Reference } \\
\text { Test }\end{array}$ & Setting and country \\
\hline Mclsaac 2002 & $\begin{array}{l}\text { Women } \geq 16 \text { y presenting with } \\
\text { symptoms of UTI }\end{array}$ & $N=231$ & $\begin{array}{l}M=43.9 \\
(20-92)\end{array}$ & $53.2 \%$ & $\geq 10^{2} \mathrm{CFU} / \mathrm{ml}$ & $\begin{array}{l}4 \text { urban academic family medicine } \\
\text { clinics in Canada }\end{array}$ \\
\hline Mclsaac 2007 & $\begin{array}{l}\text { Women } \geq 16 \text { y presenting with } \\
\text { symptoms of UTI }\end{array}$ & $N=331$ & $\begin{array}{l}M=45.2 \\
(16-99)\end{array}$ & $62.8 \%$ & $\geq 10^{2} \mathrm{CFU} / \mathrm{ml}$ & $\begin{array}{l}225 \text { Physicians from every } \\
\text { province in Canada }\end{array}$ \\
\hline \multirow[t]{3}{*}{ Lawson 1973} & $\begin{array}{l}\text { Women presenting with } \\
\text { symptoms of UTI }\end{array}$ & $N=343$ & $M=?(15-55)$ & $34.4 \%$ & $\geq 10^{2} \mathrm{CFU} / \mathrm{ml}$ & 2 general practices in the UK \\
\hline & & & & & $\geq 10^{3} \mathrm{CFU} / \mathrm{ml}$ & \\
\hline & & & & & $\geq 10^{5} \mathrm{CFU} / \mathrm{ml}$ & \\
\hline \multirow[t]{2}{*}{$\begin{array}{l}\text { Nazareth \& } \\
\text { King } 1993\end{array}$} & $\begin{array}{l}\text { Women presenting with } \\
\text { symptoms of lower UTI }\end{array}$ & $N=54$ & $\begin{array}{l}M=29 \\
(16-45)\end{array}$ & $27.8 \%$ & $\geq 10^{2} \mathrm{CFU} / \mathrm{ml}$ & 2 general practices in the UK \\
\hline & & & & & $\geq 10^{3} \mathrm{CFU} / \mathrm{ml}$ & \\
\hline \multirow[t]{2}{*}{ Little 2006} & Women with suspected UTI & $N=408$ & $M=?(17-70)$ & $62.3 \%$ & $\geq 10^{2} \mathrm{CFU} / \mathrm{ml}$ & 67 general practices in the UK \\
\hline & & & & & $\geq 10^{3} \mathrm{CFU} / \mathrm{ml}$ & \\
\hline \multirow[t]{2}{*}{ Little 2009} & Women with suspected UTI & $N=431$ & $M=?(17-70)$ & $66.6 \%$ & $\geq 10^{2} \mathrm{CFU} / \mathrm{ml}$ & 62 general practices in the UK \\
\hline & & & & & $\geq 10^{3} \mathrm{CFU} / \mathrm{ml}$ & \\
\hline \multirow[t]{2}{*}{$\begin{array}{l}\text { Dobbs \& } \\
\text { Fleming } 1987\end{array}$} & $\begin{array}{l}\text { Women presenting with } \\
\text { symptoms of UTI }\end{array}$ & $N=238$ & $M=?(?)$ & $35.7 \%$ & $\geq 10^{2} \mathrm{CFU} / \mathrm{ml}$ & 3 general practices in the UK \\
\hline & & & & & $\geq 10^{3} \mathrm{CFU} / \mathrm{ml}$ & \\
\hline \multirow[t]{3}{*}{ Mond 1965} & Women with symptoms of UTI & $N=83$ & $\mathrm{M}=?$ (?) & $45.8 \%$ & $\geq 10^{2} \mathrm{CFU} / \mathrm{ml}$ & 1 general practice in the UK \\
\hline & & & & & $\geq 10^{3} \mathrm{CFU} / \mathrm{ml}$ & \\
\hline & & & & & $\geq 10^{5} \mathrm{CFU} / \mathrm{ml}$ & \\
\hline \multirow[t]{3}{*}{$\begin{array}{l}\text { Medina- } \\
\text { Bombardo } 2003\end{array}$} & $\begin{array}{l}\text { Women presenting with } \\
\text { symptoms of UTI }\end{array}$ & $N=343$ & $\begin{array}{l}M=44 \\
(15-90)\end{array}$ & $48.4 \%$ & $\geq 10^{2} \mathrm{CFU} / \mathrm{ml}$ & $\begin{array}{l}18 \text { primary health care centres in } \\
\text { Spain }\end{array}$ \\
\hline & & & & & $\geq 10^{3} \mathrm{CFU} / \mathrm{ml}$ & \\
\hline & & & & & $\geq 10^{5} \mathrm{CFU} / \mathrm{ml}$ & \\
\hline \multirow[t]{2}{*}{$\begin{array}{l}\text { Dans \& Klaus } \\
1975\end{array}$} & Women complaining of dysuria & $N=84$ & $\begin{array}{l}M=26 \\
(19-60)\end{array}$ & $46.4 \%$ & $\geq 10^{2} \mathrm{CFU} / \mathrm{ml}$ & Adult walk-in clinic in the US \\
\hline & & & & & $\geq 10^{3} \mathrm{CFU} / \mathrm{ml}$ & \\
\hline \multirow[t]{2}{*}{ Gallagher 1965} & Women with symptoms of UTI & $N=130$ & $M=?$ (?) & $59.2 \%$ & & $\begin{array}{l}\text { Urban general practices in New } \\
\text { Zealand }\end{array}$ \\
\hline & & & & & $\geq 10^{3} \mathrm{CFU} / \mathrm{ml}$ & \\
\hline \multirow[t]{3}{*}{ Fahey 2003} & $\begin{array}{l}\text { Women presenting with } \\
\text { symptoms of UTI }\end{array}$ & $N=85$ & $M=(?)$ & $35.7 \%$ & $\geq 10^{2} \mathrm{CFU} / \mathrm{ml}$ & 8 general practices in the UK \\
\hline & & & & & $\geq 10^{3} \mathrm{CFU} / \mathrm{ml}$ & \\
\hline & & & & & $\geq 10^{5} \mathrm{CFU} / \mathrm{ml}$ & \\
\hline \multirow[t]{3}{*}{ Baerheim 2003} & $\begin{array}{l}\text { Women with acute dysuria/ } \\
\text { frequency }\end{array}$ & $N=252$ & $\begin{array}{l}M=46 \text { for UTI } \\
+\end{array}$ & $63.3 \%$ & $\geq 10^{2} \mathrm{CFU} / \mathrm{ml}$ & 8 general practices in Norway \\
\hline & & & & & $\geq 10^{3} \mathrm{CFU} / \mathrm{ml}$ & \\
\hline & & & $\begin{array}{l}M=42 \text { for } \\
\text { UTI-(18-87) }\end{array}$ & & $\geq 10^{5} \mathrm{CFU} / \mathrm{ml}$ & \\
\hline \multirow[t]{2}{*}{ Osterberg 1996} & $\begin{array}{l}\text { Women with symptoms of } \\
\text { dysuria/frequency }\end{array}$ & $N=214$ & $\begin{array}{l}M=24 \\
(15-35)\end{array}$ & $51.4 \%$ & $\geq 10^{2} \mathrm{CFU} / \mathrm{ml}$ & $\begin{array}{l}5 \text { primary health care centres in } \\
\text { Sweden }\end{array}$ \\
\hline & & & & & $\geq 10^{3} \mathrm{CFU} / \mathrm{ml}$ & \\
\hline \multirow{3}{*}{$\begin{array}{l}\text { Hummers- } \\
\text { Pradier } 2005\end{array}$} & Women with symptoms of UTI & $N=227$ & $M=53(?)$ & $79.3 \%$ & $\geq 10^{2} \mathrm{CFU} / \mathrm{ml}$ & 36 general practices in Germany \\
\hline & & & & $68.7 \%$ & $\geq 10^{3} \mathrm{CFU} / \mathrm{ml}$ & \\
\hline & & & & $49.3 \%$ & $\geq 10^{5} \mathrm{CFU} / \mathrm{ml}$ & \\
\hline \multirow[t]{3}{*}{ O'Brien 2007} & $\begin{array}{l}\text { Women with clinically suspected } \\
\text { uncomplicated UTI }\end{array}$ & $N=111$ & $M=54(?)$ & $32.4 \%$ & $\geq 10^{2} \mathrm{CFU} / \mathrm{ml}$ & 9 general practices in the UK \\
\hline & & & & & $\geq 10^{3} \mathrm{CFU} / \mathrm{ml}$ & \\
\hline & & & & & $\geq 10^{5} \mathrm{CFU} / \mathrm{ml}$ & \\
\hline
\end{tabular}




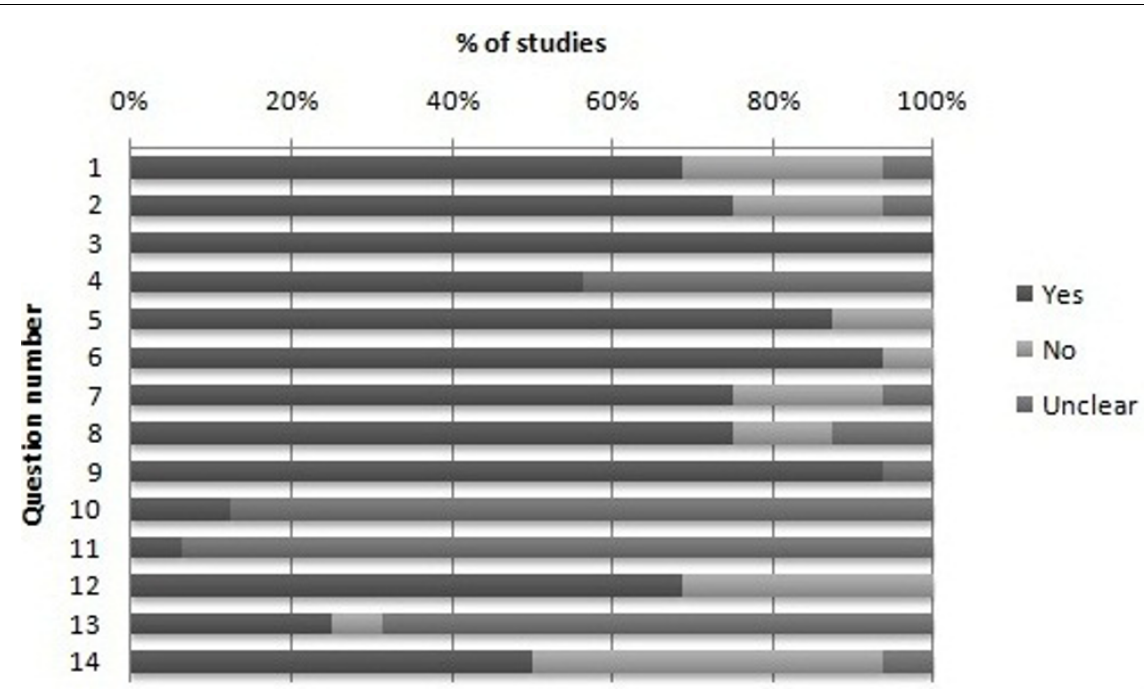

Figure 2 Quality assessment. Included questions from the Quadas Tool: [19] 1. Was the spectrum of patient's representative of the patients who will receive the test in practice? (Q1). 2. Were selection criteria clearly described? (Q2). 3. Is the reference standard likely to correctly classify the target condition? (Q3). 4. Is the time period between reference standard and index test short enough to be reasonably sure that the target condition did not change between the two tests? (Q4). 5. Did the whole sample or a random selection of the sample receive verification using a reference standard of diagnosis? (Q5). 6. Did patients receive the same reference standard regardless of their symptoms and signs? (Q6). 7. Were all signs and symptoms clearly defined? (Q7). 8. Was the execution of the urine culture described in sufficient detail to permit replication? (Q8). 9. Were signs and symptoms interpreted without knowledge of the results of urine culture? (Q9). 10. Were the results of the urine culture interpreted without knowledge of the symptoms and signs? (Q10). 11. Were uninterpretable/intermediate test results reported? (Q11). 12. Were withdrawals from the study explained? (Q12). Additional question: [20]. 13. Were the patients selected consecutively? (Q13). 14. Were statistical tests for main outcome adequate? (Q14).

region (amount of variation between studies) is also wide for most symptoms and signs across the different diagnostic thresholds, as reflected in the large values for the variance of logit-transformed sensitivity and specificity, with the exception of hematuria.

\section{Bayesian analysis and near patient testing (dipstick)}

Using Bayes theorem the post-test probability across the three threshold levels are presented in table 6. Most notable, presence of hematuria increases the pre-test probability from $65.1 \%$ to $75.8 \%$ (95\% CI 70.9 - 80.1)

Table 2 Summary estimates of sensitivity and specificity using a bivariate random effects model $\left(10^{2}\right)$

\begin{tabular}{|c|c|c|c|c|c|c|c|c|}
\hline SYMPTOM & $\begin{array}{l}\text { No. of } \\
\text { studies }\end{array}$ & $\begin{array}{l}\text { No. of } \\
\text { Patient }\end{array}$ & Sensitivity & $(95 \% \mathrm{CI})$ & $\begin{array}{l}\text { Variance Logit } \\
\text { (sensitivity) }\end{array}$ & Specificity & $(95 \% \mathrm{Cl})$ & $\begin{array}{c}\text { Variance Logit } \\
\text { (specificity) }\end{array}$ \\
\hline Dysuria $^{a}$ & 14 & 3407 & 0.80 & $(0.74-0.86)$ & 0.40 & 0.38 & $(0.31-0.46)$ & 0.33 \\
\hline Frequency $^{\mathbf{b}}$ & 13 & 2807 & 0.88 & $(0.83-0.92)$ & 0.41 & 0.20 & $(0.14-0.28)$ & 0.58 \\
\hline Back pain ${ }^{c}$ & 4 & 635 & 0.38 & $(0.26-0.52)$ & 0.22 & 0.57 & $(0.40-0.73)$ & 0.43 \\
\hline Fever $^{d}$ & 7 & 1250 & 0.10 & $(0.04-0.21)$ & 1.19 & 0.92 & $(0.83-0.97)$ & 1.07 \\
\hline Flank pain ${ }^{\mathrm{e}}$ & 6 & 1340 & 0.26 & $(0.19-0.35)$ & 0.21 & 0.69 & $(0.64-0.74)$ & 0.04 \\
\hline Hematuria & 7 & 1078 & 0.25 & $(0.21-0.29)$ & 0.01 & 0.85 & $(0.81-0.89)$ & 0.05 \\
\hline $\begin{array}{l}\text { Lower } \\
\text { abdominal pain }\end{array}$ & 7 & 1470 & 0.50 & $(0.34-0.66)$ & 0.75 & 0.50 & $(0.34-0.66)$ & 0.72 \\
\hline Nocturia & 6 & 1720 & 0.59 & $(0.50-0.68)$ & 0.17 & 0.55 & $(0.49-0.61)$ & 0.06 \\
\hline Urgency $^{\mathbf{g}}$ & 9 & 2298 & 0.67 & $(0.52-0.80)$ & 0.95 & 0.45 & $(0.31-0.60)$ & 0.79 \\
\hline $\begin{array}{l}\text { Vaginal } \\
\text { discharge }\end{array}$ & 6 & 1261 & 0.15 & $(0.08-0.26)$ & 0.65 & 0.77 & $(0.62-0.88)$ & 0.75 \\
\hline
\end{tabular}

a Three studies reported dysuria as painful voiding (Mclsaac 2002, Mclsaac 2007, Medina-Bombardo 2003).

${ }^{\mathrm{b}}$ One study reported frequency as frequency/dysuria (Dans\&Klaus).

' One study reported back pain as 'back or groin pain' (O'Brien).

${ }^{d}$ One study reported fever as pyrexia (Lawson 1973).

e One study reported flank pain as loin pain (Lawson 1973).

f Different definitions were used: 'Suprapubic pain' (Hummer-Pradier 2005), Suprapubic pressure' (Baerheim), 'abdominal pain' (Fahey 2003).

${ }^{g}$ One study reported urgency as urgency/frequency (Hummers-Pradier 2005). 
Table 3 Summary estimates of sensitivity and specificity, using a bivariate random effects model $\left(10^{3}\right)$

\begin{tabular}{|c|c|c|c|c|c|c|c|c|}
\hline SYMPTOM & $\begin{array}{l}\text { No. of } \\
\text { studies }\end{array}$ & $\begin{array}{l}\text { No. of } \\
\text { Patient }\end{array}$ & Sensitivity & (95\% Cl) & $\begin{array}{c}\text { Variance Logit } \\
\text { (sensitivity) }\end{array}$ & Specificity & (95\% Cl) & $\begin{array}{l}\text { Variance Logit } \\
\text { (specificity) }\end{array}$ \\
\hline Dysuria $^{a}$ & 12 & 2845 & 0.79 & $(0.72-0.85)$ & 0.39 & 0.39 & $(0.31-0.49)$ & 0.40 \\
\hline Frequency $^{\mathbf{b}}$ & 11 & 2246 & 0.88 & $(0.82-0.92)$ & 0.43 & 0.21 & $(0.14-0.31)$ & 0.64 \\
\hline Back pain ${ }^{c}$ & 4 & 635 & 0.38 & $(0.26-0.52)$ & 0.22 & 0.57 & $(0.40-0.73)$ & 0.43 \\
\hline Fever $^{d}$ & 6 & 926 & 0.12 & $(0.05-0.26)$ & 1.15 & 0.91 & $(0.80-0.97)$ & 1.16 \\
\hline Flank pain & 4 & 783 & 0.29 & $(0.18-0.43)$ & 0.31 & 0.65 & $(0.59-0.70)$ & 0.01 \\
\hline Hematuria & 6 & 854 & 0.22 & $(0.18-0.27)$ & 0.02 & 0.87 & $(0.81-0.91)$ & 0.11 \\
\hline $\begin{array}{l}\text { Lower } \\
\text { abdominal pain }\end{array}$ & 5 & 914 & 0.44 & $(0.26-0.64)$ & 0.78 & 0.58 & $(0.37-0.77)$ & 0.86 \\
\hline Nocturia & 5 & 1492 & 0.59 & $(0.48-0.70)$ & 0.22 & 0.57 & $(0.51-0.62)$ & 0.04 \\
\hline Urgency $^{\mathrm{g}}$ & 7 & 1739 & 0.62 & $(0.46-0.76)$ & 0.72 & 0.51 & $(0.35-0.68)$ & 0.78 \\
\hline
\end{tabular}

${ }^{a}$ One study reported dysuria as painful voiding (Medina-Bombardo 2003)

b Two studies reported frequency/dysuria (Dans\&Klaus, Wigton: training and validation set)

c One study reported back pain as 'back or groin pain' (O'Brien)

d One study reported fever as pyrexia (Lawson 1973)

e One study reported flank pain as loin pain (Lawson 1973)

f Different definitions were used: 'Suprapubic pain' (Hummer-Pradier 2005), Suprapubic pressure' (Baerheim), 'abdominal pain' (Fahey 2003)

${ }^{g}$ One study reported urgency as urgency/frequency (Hummers-Pradier 2005)

using $\geq 10^{2} \mathrm{CFU} / \mathrm{ml}$ and to $67.4 \%$ (95\% CI 60.6 - 73.6) using $\geq 10^{3} \mathrm{CFU} / \mathrm{ml}$. Presence of vaginal discharge decreases the pre-test probability from $65.1 \%$ to $54.1 \%$ (95\% CI 48.3 - 59.9). The probability of a UTI increases to $93.3 \%\left(\geq 10^{2} \mathrm{CFU} / \mathrm{ml}\right)$ and $90.1 \%\left(\geq 10^{3} \mathrm{CFU} / \mathrm{ml}\right)$ when the presence of hematuria is combined with a positive dipstick test for nitrites (table 7). Combining the presence of hematuria with a positive dipstick test for leucocyte-esterase increases the probability to $81 \%$ and $73.8 \%$ respectively (table 8 ). The post-test probability of UTI when the presence of dysuria, frequency, nocturia, hematuria and urgency is combined with either positive dipstick test for leucocyte-esterase or a combination of nitrites and leucocyte-esterase is also lower relative to positive symptoms combined with nitrites alone (table 8,9$)$. In contrast, the presence of vaginal discharge combined with a negative dipstick test result for nitrites reduces the probability of UTI to $38.4 \%$ (table 7). The presence of vaginal discharge combined with a negative result for combined nitrites and leucocyte-esterase dipstick test reduces the post-test probability further to $15 \%$ (table 9).

\section{Discussion}

\section{Principal findings}

Individual symptoms and signs suggestive of a UTI have modest diagnostic discriminative value when assessed against three reference standard thresholds for UTI. Dysuria, frequency and urgency have a higher sensitivity than specificity and are more useful in ruling out a UTI diagnosis when absent across all three reference standard thresholds $\geq 10^{2} \mathrm{CFU} / \mathrm{ml}, \geq 10^{3} \mathrm{CFU} / \mathrm{ml}$ and $\geq 10^{5}$ $\mathrm{CFU} / \mathrm{ml}$. In contrast, hematuria has a higher specificity than sensitivity and is more useful in ruling in a diagnosis of UTI when present across the reference standard thresholds $\geq 10^{2} \mathrm{CFU} / \mathrm{ml}$ and $\geq 10^{3} \mathrm{CFU} / \mathrm{ml}$. Combining positive dipstick test results, particularly tests for nitrites, with symptoms increases post-test probability of a UTI. In particular, presence of hematuria combined with a positive dipstick test result for nitrites increases

Table 4 Summary estimates of sensitivity and specificity using a bivariate random effects model $\left(10^{5}\right)$

\begin{tabular}{|c|c|c|c|c|c|c|c|c|}
\hline SYMPTOM & $\begin{array}{l}\text { No. of } \\
\text { studies }\end{array}$ & $\begin{array}{l}\text { No. of } \\
\text { Patient }\end{array}$ & Sensitivity & $(95 \% \mathrm{CI})$ & $\begin{array}{l}\text { Variance Logit } \\
\text { (sensitivity) }\end{array}$ & Specificity & $(95 \% \mathrm{Cl})$ & $\begin{array}{c}\text { Variance Logit } \\
\text { (specificity) }\end{array}$ \\
\hline Dysuria $^{a}$ & 7 & 1584 & 0.78 & $(0.68-0.86)$ & 0.42 & 0.36 & $(0.26-0.48)$ & 0.37 \\
\hline Frequency & 6 & 1333 & 0.90 & $(0.85-0.94)$ & 0.22 & 0.17 & $(0.11-026)$ & 0.38 \\
\hline Fever $^{d}$ & 4 & 742 & 0.10 & $(0.04-0.23)$ & 0.82 & 0.89 & $(0.75-0.95)$ & 0.79 \\
\hline $\begin{array}{l}\text { Lower } \\
\text { abdominal pain }\end{array}$ & 4 & 784 & 0.40 & $(0.21-0.62)$ & 0.74 & 0.64 & $(0.41-0.82)$ & 0.83 \\
\hline Urgency $^{g}$ & 4 & 1039 & 0.75 & $(0.69-0.80)$ & 0.05 & 0.36 & $(0.27-0.46)$ & 0.14 \\
\hline
\end{tabular}

${ }^{a}$ One study reported dysuria as painful voiding (Medina-Bombardo 2003).

d One study reported fever as pyrexica (Lawson 1973.

f Different definitions were used: 'Suprapubic pain' (Hummer-Pradier 2005), Suprapubic pressure' (Baerheim), 'abdominal pain' (Fahey 2003).

${ }^{g}$ One study reported urgency as urgency/frequency (Hummers-Pradier 2005). 
Table 5 Summary estimates of positive and negative likelihood ratio's, using a bivariate random effects model (10 ${ }^{2}$, $10^{3}, 10^{5}$ )

\begin{tabular}{|c|c|c|c|c|c|c|c|c|c|c|c|c|}
\hline \multirow[b]{2}{*}{ SYMPTOM } & \multicolumn{4}{|c|}{$\geq 10^{2} \mathrm{CFU} / \mathrm{ml}$} & \multicolumn{4}{|c|}{$\geq 10^{3} \mathrm{CFU} / \mathrm{ml}$} & \multicolumn{4}{|c|}{$\geq 10^{5} \mathrm{CFU} / \mathrm{ml}$} \\
\hline & +LR & $(95 \% \mathrm{Cl})$ & $-\mathrm{LR}$ & $(95 \% \mathrm{Cl})$ & $+\mathrm{LR}$ & $(95 \% \mathrm{Cl})$ & $-\mathrm{LR}$ & $(95 \% \mathrm{Cl})$ & $+\mathrm{LR}$ & $(95 \% \mathrm{Cl})$ & -LR & $(95 \% \mathrm{Cl})$ \\
\hline Dysuria & 1.30 & $(1.20-1.41)$ & 0.51 & $(0.43-0.61)$ & 1.31 & $(1.18-1.45)$ & 0.53 & $(0.43-0.64)$ & 1.22 & $(1.11-1.34)$ & 0.61 & $(0.50-0.74)$ \\
\hline Frequency & 1.10 & $(1.04-1.16)$ & 0.60 & $(0.49-0.74)$ & 1.12 & $(1.03-1.19)$ & 0.59 & $(0.46-0.76)$ & 1.09 & $(1.02-1.16)$ & 0.58 & $(0.42-0.79)$ \\
\hline Back pain & 0.90 & $(0.71-1.14)$ & 1.07 & $(0.90-1.28)$ & 0.90 & $(0.71-1.14)$ & 1.07 & $(0.90-1.28)$ & & & & \\
\hline Fever & 1.28 & $(0.64-2.58)$ & 0.98 & $(0.91-1.05)$ & 1.39 & $(0.63-3.07)$ & 0.96 & $(0.88-1.06)$ & 0.90 & $(0.45-1.80)$ & 1.01 & $(0.93-1.10$ \\
\hline Flank pain & 0.85 & $(0.67-1.08)$ & 1.07 & $(0.98-1.17)$ & 0.83 & $(0.56-1.24)$ & 1.09 & $(0.92-1.29)$ & & & & \\
\hline Hematuria & 1.72 & $(1.30-2.27)$ & 0.88 & $(0.83-0.93)$ & 1.68 & $(1.06-2.66)$ & 0.89 & $(0.82-0.98)$ & & & & \\
\hline Lower abdominal pain & 1.01 & $(0.89-1.15)$ & 0.99 & $(0.87-1.13)$ & 1.06 & $(0.88-1.29)$ & 0.96 & $(0.83-1.10)$ & 1.10 & $(0.87-1.38)$ & 0.94 & $(0.82-1.08)$ \\
\hline Nocturia & 1.30 & $(1.08-1.56)$ & 0.75 & $(0.60-0.94)$ & 1.37 & $(1.13-1.65)$ & 0.72 & $(0.56-0.93)$ & & & & \\
\hline Urgency & 1.22 & $(1.11-1.34)$ & 0.73 & $(0.62-0.86)$ & 1.28 & $(1.11-1.47)$ & 0.74 & $(0.64-0.85)$ & 1.17 & $(1.04-1.31)$ & 0.70 & $(0.57-0.86)$ \\
\hline Vaginal discharge & 0.65 & $(0.51-0.83)$ & 1.10 & $(1.01-1.20)$ & & & & & & & & \\
\hline
\end{tabular}

the post-test probability from $75.8 \%$ to $93.3 \%$ at $\geq 10^{2}$ $\mathrm{CFU} / \mathrm{ml}$ and from $67.4 \%$ to $90.1 \%$ at $\geq 10^{3} \mathrm{CFU} / \mathrm{ml}$. Similarly, presence of dysuria combined with a positive dipstick test result for nitrites increases post- test probability from between $51.1 \%$ to $82.2 \%$ at $\geq 10^{5} \mathrm{CFU} / \mathrm{ml}$.

\section{Context of previous studies}

The findings of this systematic review are consistent with a previous systematic review which concluded that no sign or symptom on its own is powerful enough to 'rule in' or 'rule out' the diagnosis of UTI [14]. However, the relative diagnostic importance of individual symptoms and signs varies between this review and the previous systematic review [14]. The previous systematic review found that presence of dysuria, frequency, hematuria, back pain and costovertebral angle tenderness increase the probability of UTI using a diagnostic threshold ranging from between $\geq 10^{2} \mathrm{CFU} / \mathrm{ml}$ and $\geq 10^{5} \mathrm{CFU} / \mathrm{ml}$, also history of vaginal discharge, history of vaginal irritation and vaginal discharge on examination decrease the probability of a UTI. In this systematic review we found that dysuria and frequency increase the probability of UTI across different reference standard thresholds $\geq 10^{2}$ $\mathrm{CFU} / \mathrm{ml}, \geq 10^{3} \mathrm{CFU} / \mathrm{ml}$ and $\geq 10^{5} \mathrm{CFU} / \mathrm{ml}$. Hematuria is

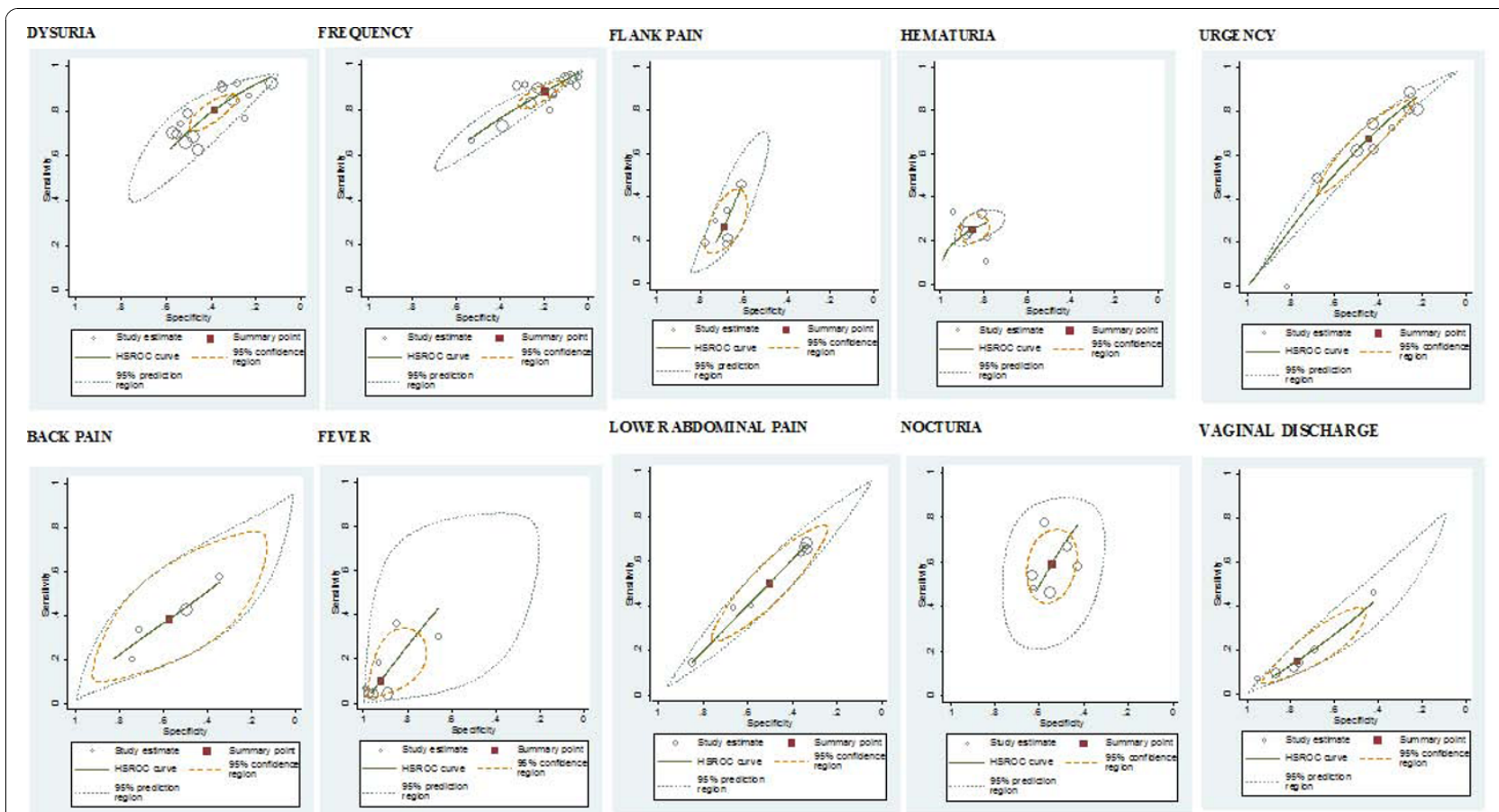

Figure 3 Receiver operating characteristic graphs with 95\%-confidence region and $95 \%$ - prediction region for each sign and symptom (10 ${ }^{2}$ ). 


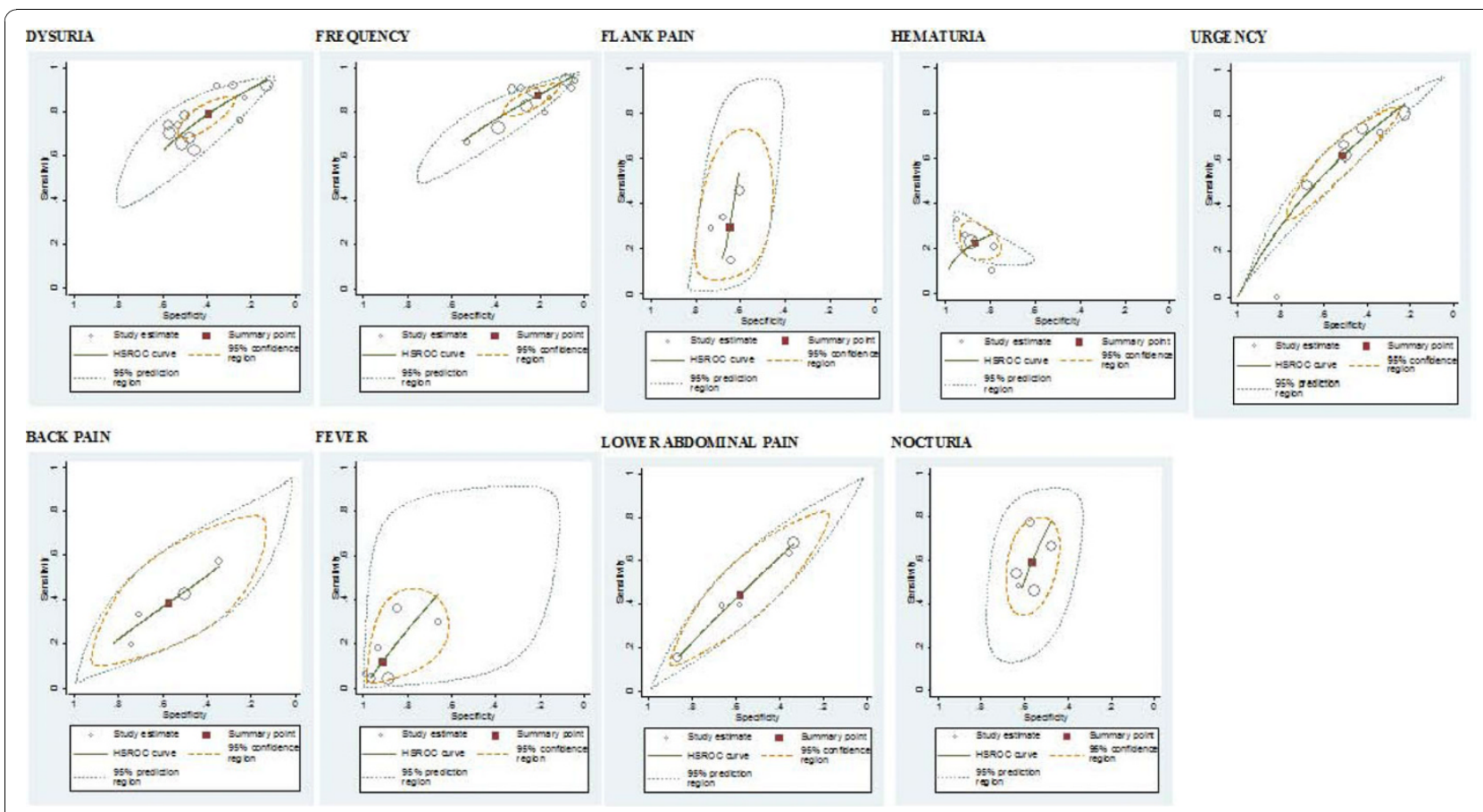

Figure 4 Receiver operating characteristic graphs with $95 \%$-confidence region and $95 \%$ - prediction region for each sign and symptom $\left(10^{3}\right)$.

also significant in the present study using a diagnostic threshold of $\geq 10^{2} \mathrm{CFU} / \mathrm{ml}$ and $\geq 10^{3} \mathrm{CFU} / \mathrm{ml}$. However, in contrast to the previous systematic review back pain is not significantly associated with UTI across the different reference standard thresholds. Vaginal discharge is identified as an important symptom for decreasing the probability of UTI in the present study.

Such differences may be an artefact of different methodological approaches taken. Firstly, the previous systematic review pooled all studies irrespective of the reference standard threshold used, whereas the present study sought to determine the importance of individual symptoms and signs at different reference standard thresholds. In addition, our inclusion criteria was more conservative, excluding studies which involved self-diagnosis, case-control study designs and different healthcare settings (i.e. not primary care settings) where the prevalence of symptoms may differ and increase the chance of spectrum bias.

\section{Strengths and limitations of this study}

The systematic search, the conservative inclusion criteria, the inclusion of additional data from authors, and the quality assessment of the included studies can be seen as strengths of this study. In addition, given the lack of consensus regarding reference standard thresholds for UTI, the current study is the first study to determine the diagnostic accuracy of symptoms and signs across the three thresholds $\geq 10^{2} \mathrm{CFU} / \mathrm{ml}, \geq 10^{3} \mathrm{CFU} / \mathrm{ml}$ and $\geq 10^{5} \mathrm{CFU} / \mathrm{ml}$. Lastly, this study highlights the additional importance of using dipstick test, particularly tests for nitrites, as an additional diagnostic tool when ruling in a UTI diagnosis based on particular symptomatology.

We acknowledge that this review has limitations. Variability of diagnostic accuracy estimates across studies is high. This may be due to the fact that we did not restrict the age of women included in the meta-analysis. It is known that the prevalence of UTI differs across age groups, peaking at 15-24 years and greater than 65 years [45]. In addition definitions used to describe individual symptoms and signs vary across studies. For example, 'lower abdominal pain' has been defined as 'suprapubic pain' [4,6,7], 'suprapubic pressure' [42] or 'abdominal pain' [24]. Furthermore, as the bivariate random effects model is used symptoms and signs are analysed, when at least 4 studies are included. Therefore few symptoms and signs are excluded from our meta-analysis particularly at the higher reference standard threshold of $\geq 10^{5} \mathrm{CFU} / \mathrm{ml}$. Finally, while the probability of UTI increases when the presence of certain symptoms are combined with positive dipstick test results, it is important to acknowledge that the predictive value of the dipstick test result, was taken from a meta-analysis which included men and pregnant women [23].

\section{Implications for practice}

Individual symptoms and signs will modestly increase the post-test probability and cannot accurately 'rule in' 


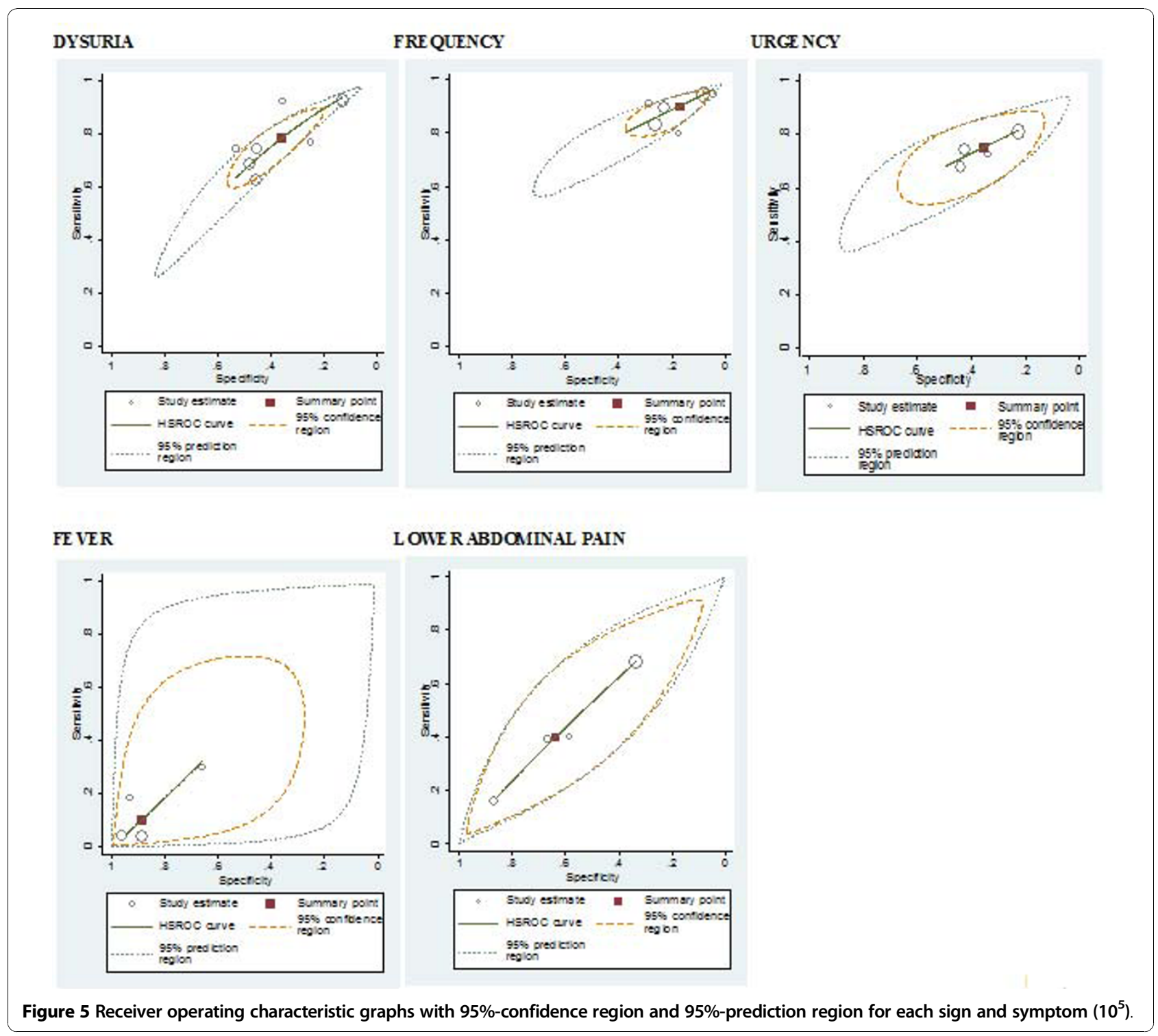

or 'rule out' the diagnosis of a UTI. Subgroup analysis shows improved diagnostic accuracy using lower reference standards of $\geq 10^{2} \mathrm{CFU} / \mathrm{ml}$ and of $\geq 10^{3} \mathrm{CFU} / \mathrm{ml}$. In addition, combining nitrite dipstick test results with clinical symptoms and signs is useful for ruling in a UTI diagnosis and deciding on the optimal patient management strategy. More recently, formal clinical prediction rules for UTI that incorporate the independent effects of symptoms and signs into a "risk score" have been proposed as an alternative management strategy when considering antibiotic treatment [8]. This approach appears to be equivalent to alternative management strategies for UTI in women including empirical immediate antibiotics, empirical delayed antibiotics, or use of near-patient testing with a dipstick in terms of duration or severity of symptoms. However, in terms of antibiotic usage, use of a dipstick results in fewer antibiotics being prescribed when compared to immediate empirical antibiotics or use of a UTI "risk score" [46].

\section{Future studies}

The current approach of evaluating symptoms and signs as a diagnostic test is in general two-dimensional, and ignores symptom severity $[8,9,28]$ In the future, focusing on severity of symptoms may provide more valuable diagnostic information.

\section{Conclusions}

Individual symptoms and signs, independent of reference standard threshold have a modest ability to 'rule in' or 'rule out' the diagnosis of UTI. Use of a dipstick test enhances diagnostic utility and reduces the chance 
Table 6 Post-test probability of significant symptoms across three different reference standards $10^{2}, 10^{3}$ and $10^{5} \mathrm{CFU} /$ ml

\begin{tabular}{|c|c|c|c|}
\hline Symptom & Reference standard* & +LR $(95 \% \mathrm{Cl})$ & $\begin{array}{l}\text { Post-test probability } \\
(95 \% \mathrm{Cl})(\%)\end{array}$ \\
\hline \multirow[t]{3}{*}{ Dysuria } & $10^{2} \mathrm{CFU} / \mathrm{ml}$ & $1.30(1.20-1.41)$ & $71.0(70.0-71.0)$ \\
\hline & $10^{3} \mathrm{CFU} / \mathrm{ml}$ & $1.31(1.18-1.45)$ & $62.3(61.0-63.6)$ \\
\hline & $10^{5} \mathrm{CFU} / \mathrm{ml}$ & $1.22(1.11-1.34)$ & $51.1(49.5-52.8)$ \\
\hline \multirow[t]{3}{*}{ Frequency } & $10^{2} \mathrm{CFU} / \mathrm{ml}$ & $1.10(1.04-1.16)$ & $67.8(67.0-68.5)$ \\
\hline & $10^{3} \mathrm{CFU} / \mathrm{ml}$ & $1.12(1.03-1.19)$ & $58.6(57.5-59.5)$ \\
\hline & $10^{5} \mathrm{CFU} / \mathrm{ml}$ & $1.09(1.02-1.16)$ & $47.8(46.7-49.0)$ \\
\hline \multirow[t]{2}{*}{ Hematuria } & $10^{2} \mathrm{CFU} / \mathrm{ml}$ & $1.72(1.30-2.27)$ & $75.8(70.9-80.1)$ \\
\hline & $10^{3} \mathrm{CFU} / \mathrm{ml}$ & $1.68(1.06-2.66)$ & $67.4(60.6-73.6)$ \\
\hline \multirow[t]{2}{*}{ Nocturia } & $10^{2} \mathrm{CFU} / \mathrm{ml}$ & $1.30(1.08-1.56)$ & $69.4(67.3-71.3)$ \\
\hline & $10^{3} \mathrm{CFU} / \mathrm{ml}$ & $1.37(1.13-1.65)$ & $60.8(58.4-63.3)$ \\
\hline \multirow[t]{3}{*}{ Urgency } & $10^{2} \mathrm{CFU} / \mathrm{ml}$ & $1.22(1.11-1.34)$ & $69.8(68.5-71.1)$ \\
\hline & $10^{3} \mathrm{CFU} / \mathrm{ml}$ & $1.28(1.11-1.47)$ & $61.7(59.9-63.6)$ \\
\hline & $10^{5} \mathrm{CFU} / \mathrm{ml}$ & $1.17(1.04-1.34)$ & $49.1(47.1-51.1)$ \\
\hline Vaginal discharge & $10^{2} \mathrm{CFU} / \mathrm{ml}$ & $0.65(0.51-0.83)$ & $54.1(48.3-59.9)$ \\
\hline
\end{tabular}

* Pretest probability is $65.1 \%$ at $\geq 10^{2} \mathrm{CFU} / \mathrm{ml} ; 55.4 \%$ at $\geq 10^{3} \mathrm{CFU} / \mathrm{ml}$ and $44.8 \%$ at $\geq 10^{5} \mathrm{CFU} / \mathrm{ml}$.

Table 7 Post-test probability of significant symptoms with a positive (LR 4.42) or negative dipstick (LR 0.53 ) test for nitrites [23]

\begin{tabular}{|c|c|c|c|c|}
\hline Symptom & Reference standard & $\begin{array}{l}\text { Pre-test probability } \\
(95 \% \mathrm{Cl})(\%)\end{array}$ & $\begin{array}{l}\text { Post-test probability } \\
(95 \% \mathrm{Cl})(\mathrm{LR}+)\end{array}$ & $\begin{array}{l}\text { Post-test probability } \\
(95 \% \mathrm{Cl})(\mathrm{LR}-)\end{array}$ \\
\hline \multirow[t]{3}{*}{ Dysuria } & $10^{2} \mathrm{CFU} / \mathrm{ml}$ & $71.0(70.0-71.0)$ & $91.5(91.2-92.0)$ & $56.5(55.3-56.5)$ \\
\hline & $10^{3} \mathrm{CFU} / \mathrm{ml}$ & $62.3(61.0-63.6)$ & $88.0(87.4-88.5)$ & $46.7(45.3-48.1)$ \\
\hline & $10^{5} \mathrm{CFU} / \mathrm{ml}$ & $51.1(49.5-52.8)$ & $82.2(81.2-83.2)$ & $35.6(34.2-37.2)$ \\
\hline \multirow[t]{3}{*}{ Frequency } & $10^{2} \mathrm{CFU} / \mathrm{ml}$ & $67.8(67.0-68.5)$ & $90.3(90.0-91.0)$ & $52.7(51.8-53.5)$ \\
\hline & $10^{3} \mathrm{CFU} / \mathrm{ml}$ & $58.6(57.5-59.5)$ & $86.2(85.7-87.0)$ & $42.9(41.8-43.8)$ \\
\hline & $10^{5} \mathrm{CFU} / \mathrm{ml}$ & $47.8(46.7-49.0)$ & $80.2(79.5-81.0)$ & $32.7(31.7-33.7)$ \\
\hline \multirow[t]{2}{*}{ Hematuria } & $10^{2} \mathrm{CFU} / \mathrm{ml}$ & $75.8(70.9-80.1)$ & $93.3(91.5-95.0)$ & $62.4(56.4-68.1)$ \\
\hline & $10^{3} \mathrm{CFU} / \mathrm{ml}$ & $67.4(60.6-73.6)$ & $90.1(87.2-92.5)$ & $52.3(44.9-59.6)$ \\
\hline \multirow[t]{2}{*}{ Nocturia } & $10^{2} \mathrm{CFU} / \mathrm{ml}$ & $69.4(67.3-71.3)$ & $91.0(90.1-92.0)$ & $54.6(52.1-56.8)$ \\
\hline & $10^{3} \mathrm{CFU} / \mathrm{ml}$ & $60.8(58.4-63.3)$ & $87.3(86.1-88.4)$ & $45.1(42.7-47.8)$ \\
\hline \multirow[t]{3}{*}{ Urgency } & $10^{2} \mathrm{CFU} / \mathrm{ml}$ & $69.8(68.5-71.1)$ & $91.0(90.6-91.6)$ & $55.1(53.5-56.6)$ \\
\hline & $10^{3} \mathrm{CFU} / \mathrm{ml}$ & $61.7(59.9-63.6)$ & 87.7 (86.8-88.5) & $46.1(44.2-48.1)$ \\
\hline & $10^{5} \mathrm{CFU} / \mathrm{ml}$ & $49.1(47.1-51.1)$ & $81.0(79.7-82.2)$ & $33.8(32.1-35.6)$ \\
\hline Vaginal discharge & $10^{2} \mathrm{CFU} / \mathrm{ml}$ & $54.1(48.3-59.9)$ & $84.0(80.5-86.8)$ & $38.4(33.1-44.2)$ \\
\hline
\end{tabular}


Table 8 Post-test probability of significant symptoms with a positive (LR 1.36) or negative dipstick (LR 0.36) test for leucocyte-esterase [23]

\begin{tabular}{|c|c|c|c|c|}
\hline Symptom & Reference standard & $\begin{array}{l}\text { Pre-test probability } \\
(95 \% \mathrm{Cl})(\%)\end{array}$ & $\begin{array}{l}\text { Post-test probability } \\
(95 \% \mathrm{Cl})(\mathrm{LR}+)\end{array}$ & $\begin{array}{l}\text { Post-test probability } \\
(95 \% \mathrm{CI})(\mathrm{LR}-)\end{array}$ \\
\hline \multirow[t]{3}{*}{ Dysuria } & $10^{2} \mathrm{CFU} / \mathrm{ml}$ & $71.0(70.0-71.0)$ & $76.9(76.0-76.9)$ & $46.8(45.7-46.8)$ \\
\hline & $10^{3} \mathrm{CFU} / \mathrm{ml}$ & $62.3(61.0-63.6)$ & $69.2(68.0-70.4)$ & $37.3(36.0-38.6)$ \\
\hline & $10^{5} \mathrm{CFU} / \mathrm{ml}$ & $51.1(49.5-52.8)$ & $58.7(57.1-60.3)$ & $27.3(26.1-28.7)$ \\
\hline \multirow[t]{3}{*}{ Frequency } & $10^{2} \mathrm{CFU} / \mathrm{ml}$ & $67.8(67.0-68.5)$ & $74.1(73.4-74.7)$ & $43.1(42.2-43.9)$ \\
\hline & $10^{3} \mathrm{CFU} / \mathrm{ml}$ & $58.6(57.5-59.5)$ & $65.8(64.8-66.6)$ & 33.8 (32.8-34.6) \\
\hline & $10^{5} \mathrm{CFU} / \mathrm{ml}$ & $47.8(46.7-49.0)$ & $55.5(54.4-56.6)$ & $24.8(24.0-25.7$ \\
\hline \multirow[t]{2}{*}{ Hematuria } & $10^{2} \mathrm{CFU} / \mathrm{ml}$ & $75.8(70.9-80.1)$ & $81.0(76.8-84.6)$ & $53.0(46.7-59.2)$ \\
\hline & $10^{3} \mathrm{CFU} / \mathrm{ml}$ & $67.4(60.6-73.6)$ & $73.8(67.7-79.1)$ & $42.7(35.6-50.1)$ \\
\hline \multirow[t]{2}{*}{ Nocturia } & $10^{2} \mathrm{CFU} / \mathrm{ml}$ & $69.4(67.3-71.3)$ & $75.5(73.7-77.2)$ & $44.9(42.6-47.2)$ \\
\hline & $10^{3} \mathrm{CFU} / \mathrm{ml}$ & $60.8(58.4-63.3)$ & $67.8(65.6-70.1)$ & $35.8(33.6-38.3)$ \\
\hline \multirow[t]{3}{*}{ Urgency } & $10^{2} \mathrm{CFU} / \mathrm{ml}$ & $69.8(68.5-71.1)$ & 75.9 (74.7-77.0) & $45.4(43.9-47.0)$ \\
\hline & $10^{3} \mathrm{CFU} / \mathrm{ml}$ & $61.7(59.9-63.6)$ & $68.7(67.0-70.4)$ & 36.7 (35.0-38.6) \\
\hline & $10^{5} \mathrm{CFU} / \mathrm{ml}$ & $49.1(47.1-51.1)$ & $56.7(55.0-58.7)$ & $25.8(24.3-27.3)$ \\
\hline Vaginal discharge & $10^{2} \mathrm{CFU} / \mathrm{ml}$ & $54.1(48.3-59.9)$ & $61.6(56.0-67.0)$ & $29.8(25.2-35.0)$ \\
\hline
\end{tabular}

Table 9 Post-test probability of significant symptoms with a positive (LR 2.57) or negative dipstick (LR 0.15) test for nitrites and leucocyte-esterase combined [23]

\begin{tabular}{|c|c|c|c|c|}
\hline Symptom & Reference standard & $\begin{array}{l}\text { Pre-test probability } \\
(95 \% \mathrm{Cl})(\%)\end{array}$ & $\begin{array}{l}\text { Post-test probability } \\
(95 \% \mathrm{Cl})(\mathrm{LR}+)\end{array}$ & $\begin{array}{l}\text { Post-test probability } \\
(95 \% \mathrm{Cl})(\mathrm{LR}-)\end{array}$ \\
\hline \multirow[t]{3}{*}{ Dysuria } & $10^{2} \mathrm{CFU} / \mathrm{ml}$ & $71.0(70.0-71.0)$ & $86.3(85.7-86.3)$ & $26.9(25.9-26.9)$ \\
\hline & $10^{3} \mathrm{CFU} / \mathrm{ml}$ & $62.3(61.0-63.6)$ & 80.9(80.1-81.8) & $19.9(19.0-20.8)$ \\
\hline & $10^{5} \mathrm{CFU} / \mathrm{ml}$ & $51.1(49.5-52.8)$ & $72.9(71.6-74.2)$ & $13.6(12.8-14.3)$ \\
\hline \multirow[t]{3}{*}{ Frequency } & $10^{2} \mathrm{CFU} / \mathrm{ml}$ & $67.8(67.0-68.5)$ & 84.4(83.9-84.8) & $24.0(23.3-24.6)$ \\
\hline & $10^{3} \mathrm{CFU} / \mathrm{ml}$ & $58.6(57.5-59.5)$ & 78.4(77.7-79.1) & $17.5(16.9-18.1)$ \\
\hline & $10^{5} \mathrm{CFU} / \mathrm{ml}$ & $47.8(46.7-49.0)$ & $70.2(69.2-71.1)$ & $12.1(11.6-12.6)$ \\
\hline \multirow[t]{2}{*}{ Hematuria } & $10^{2} \mathrm{CFU} / \mathrm{ml}$ & $75.8(70.9-80.1)$ & 89.0(86.2-91.2) & $32.0(26.8-37.6)$ \\
\hline & $10^{3} \mathrm{CFU} / \mathrm{ml}$ & $67.4(60.6-73.6)$ & $84.2(79.8-87.8)$ & $23.7(18.7-29.5)$ \\
\hline \multirow[t]{2}{*}{ Nocturia } & $10^{2} \mathrm{CFU} / \mathrm{ml}$ & $69.4(67.3-71.3)$ & $85.4(84.1-86.5)$ & $25.4(23.6-27.1)$ \\
\hline & $10^{3} \mathrm{CFU} / \mathrm{ml}$ & $60.8(58.4-63.3)$ & 80.0(78.3-81.6) & $18.9(17.4-20.6)$ \\
\hline \multirow[t]{3}{*}{ Urgency } & $10^{2} \mathrm{CFU} / \mathrm{ml}$ & $69.8(68.5-71.1)$ & 85.6(84.8-86.3) & $25.7(24.6-27.0)$ \\
\hline & $10^{3} \mathrm{CFU} / \mathrm{ml}$ & $61.7(59.9-63.6)$ & 80.5(79.3-81.8) & $19.5(18.3-20.8)$ \\
\hline & $10^{5} \mathrm{CFU} / \mathrm{ml}$ & $49.1(47.1-51.1)$ & 71.3(69.6-72.9) & $12.6(11.8-13.6)$ \\
\hline Vaginal discharge & $10^{2} \mathrm{CFU} / \mathrm{ml}$ & $54.1(48.3-59.9)$ & $75.2(71.0-79.3)$ & $15.0(12.3-18.3)$ \\
\hline
\end{tabular}


of prescribing unnecessary antibiotics. Future studies should focus on the refinement of diagnosis utilising information on severity and duration of symptoms, alone, in combination and alongside dipstick testing.

\section{Additional material}

Additional file 1: PRISMA checklist. Guidelines for the reporting on systematic reviews and meta-analyses

\section{Acknowledgements}

We would like to acknowledge Eva Hummers-Pradier, David MedinaBombardo Kathryn O'Brien, and Warren J Mclsaac for providing additional information

This work was supported by the Health Research Board (HRB) of Ireland through the HRB Centre for Primary Care Research under Grant HRC/2007/1. In addition, Leonie Giesen was funded as part of an Erasmus Exchange Student Research Fellowship between RU Nijmegen Medical School and RCSI Medical School, Dublin.

\section{Author details}

${ }^{1}$ HRB Centre for Primary Care Research, Department of General Practice, Royal College of Surgeons in Ireland, Beaux Lane House, Lower Mercer Street, Dublin 2, Ireland. 'Department of Primary and Community Care, Radboud University Nijmegen Medical Centre, 6500 HB, Nijmegen, The Netherlands.

\section{Authors' contributions}

All authors were involved in the study conception and design. LG performed a systematic search of the literature. Both LG and GC screened potential articles, evaluated the methodological quality of studies, acquired data for analysis, performed statistical analysis and interpretation of data and drafted the paper. TF, FVL and BDD critically revised the draft manuscript. All authors read and approved the final manuscript.

\section{Competing interests}

The authors declare that they have no competing interests.

Received: 15 July 2010 Accepted: 24 October 2010

Published: 24 October 2010

\section{References}

1. Verheij R, Van Dijk C, Abrahamse H, Davids R, Vanden Hoogen $H$, Braspenning J, et al: Landelijk Informatienetwerk Huisartsenzorg. Feiten en cijfers over huisartsenzorg in Nederland. Utrecht/Nijmegen. NIVEL/IQ 2009 [http://www.nivel.nl/oc2/page.asp?pageid=12694], bezocht op 6 september 2010.

2. Foxman B, Barlow R, D'Arcy H, Gillespie B, Sobel JD: Urinary tract infection: self-reported incidence and associated costs. Ann Epidemiol 2000, 10(8):509-515.

3. Kass EH: Asymptomatic infections of the urinary tract. Trans Assoc Am Physicians 1956, 69:56-64.

4. Mclsaac WJ, Moineddin R, Ross S: Validation of a decision aid to assist physicians in reducing unnecessary antibiotic drug use for acute cystitis. Arch Intern Med 2007, 167(20):2201-2206.

5. Stamm WE, Counts GW, Running KR, Fihn S, Turck M, Holmes KK: Diagnosis of coliform infection in acutely dysuric women. N Engl J Med 1982, 307(8):463-468.

6. Mclsaac WJ, Low DE, Biringer A, Pimlott N, Evans M, Glazier R: The impact of empirical management of acute cystitis on unnecessary antibiotic use. Archives of Internal Medicine 2002, 162(5):600-605.

7. Hummers-Pradier E, Ohse AM, Koch M, Heizmann WR, Kochen MM: Management of urinary tract infections in female general practice patients. Fam Pract 2005, 22(1):71-77.

8. Little P, Turner S, Rumsby K, Warner G, Moore M, Lowes JA, et al: Developing clinical rules to predict urinary tract infection in primary care settings: sensitivity and specificity of near patient tests (dipsticks) and clinical scores. Br J Gen Pract 2006, 56(529):606-612.

9. Little P, Turner S, Rumsby K, Warner G, Moore M, Lowes JA, et al: Dipsticks and diagnostic algorithms in urinary tract infection: development and validation, randomised trial, economic analysis, observational cohort and qualitative study. Health Technol Assess 2009, 13(19):1-73, iii-iv, ix-xi.

10. Osterberg E, Aspevall O, Grillner L, Persson E: Young women with symptoms of urinary tract infection. Prevalence and diagnosis of chlamydial infection and evaluation of rapid screening of bacteriuria. Scand J Prim Health Care 1996, 14(1):43-49.

11. Kouri T, Fogazzi G, Gant V, Hallander H, Hofmann W, Guder WG: European urinalysis guidelines. Scand J Clin Lab Invest 2000, 60(Suppl 231):1-96.

12. Hooton TM, Scholes D, Stapleton AE, Roberts PL, Winter C, Gupta K, et al: A prospective study of asymptomatic bacteriuria in sexually active young women. N Engl J Med 2000, 343(14):992-997.

13. Bengtsson C, Bengtsson U, Bjorkelund C, Lincoln K, Sigurdsson JA: Bacteriuria in a population sample of women: 24-year follow-up study. Results from the prospective population-based study of women in Gothenburg, Sweden. Scand J Urol Nephrol 1998, 32(4):284-289.

14. Bent S, Nallamothu BK, Simel DL, Fihn SD, Saint S: Does this woman have an acute uncomplicated urinary tract infection? JAMA 2002, 287(20):2701-2710

15. Fenwick EA, Briggs $\mathrm{AH}$, Hawke $\mathrm{Cl}$ : Management of urinary tract infection in general practice: a cost-effectiveness analysis. Br J Gen Pract 2000, 50(457):635-639

16. Barry $\mathrm{HC}$, Ebell $\mathrm{MH}$, Hickner J: Evaluation of suspected urinary tract infection in ambulatory women: a cost-utility analysis of office-based strategies. J Fam Pract 1997, 44(1):49-60.

17. Magee JT, Pritchard EL, Fitzgerald KA, Dunstan FD, Howard AJ: Antibiotic prescribing and antibiotic resistance in community practice: retrospective study, 1996-8. Bmj 1999, 319(7219):1239-1240.

18. Leeflang MM, Deeks JJ, Gatsonis C, Bossuyt PM: Systematic reviews of diagnostic test accuracy. Ann Intern Med 2008, 149(12):889-897.

19. Whiting P, Rutjes AW, Reitsma JB, Bossuyt PM, Kleijnen J: The development of QUADAS: a tool for the quality assessment of studies of diagnostic accuracy included in systematic reviews. BMC Med Res Methodol 2003, $3: 25$.

20. Crawford F, Inkster M, Kleijnen J, Fahey T: Predicting foot ulcers in patients with diabetes: a systematic review and meta-analysis. Qjm 2007, 100(2):65-86.

21. Reitsma JB, Glas AS, Rutjes AW, Scholten RJ, Bossuyt PM, Zwinderman AH: Bivariate analysis of sensitivity and specificity produces informative summary measures in diagnostic reviews. J Clin Epidemiol 2005, 58(10):982-990.

22. Deeks JJ, Altman DG: Diagnostic tests 4: likelihood ratios. BMJ 2004, 329(7458):168-169.

23. Deville WL, Yzermans JC, van Duijn NP, Bezemer PD, van der Windt DA, Bouter $L M$ : The urine dipstick test useful to rule out infections. A metaanalysis of the accuracy. BMC Urol 2004, 4:4.

24. Fahey T, Webb E, Montgomery AA, Heyderman RS: Clinical management of urinary tract infection in women: A prospective cohort study. Family Practice 2003, 20(1):1-6.

25. Nazareth I, King M: Decision making by general practitioners in diagnosis and management of lower urinary tract symptoms in women. BMJ 1993, 306(6885):1103-1106.

26. Medina-Bombardo D, Segui-Diaz M, Roca-Fusalba C, Llobera J: What is the predictive value of urinary symptoms for diagnosing urinary tract infection in women? Fam Pract 2003, 20(2):103-107.

27. Leibovici L, Alpert G, Laor A, Kalter-Leibovici O, Danon YL: A clinical model for diagnosis of urinary tract infection in young women. Arch Intern Med 1989, 149(9):2048-2050.

28. Ferry SA, Holm SE, Stenlund H, Lundholm R, Monsen TJ: The natural course of uncomplicated lower urinary tract infection in women illustrated by a randomized placebo controlled study. Scandinavian Journal of Infectious Diseases 2004, 36(4):296-301.

29. Christiaens TCM, De Meyere M, Verschraegen G, Peersman W, Heytens S, De Maeseneer JM: Randomised controlled trial of nitrofurantoin versus placebo in the treatment of uncomplicated urinary tract infection in adult women. British Journal of General Practice 2002, 52(482):729-734.

30. Park J, Min K, Kang D: The efficacy and safety of a once-daily extendedrelease ciprofloxacin tablet for the empirical treatment of symptomatic 
uncomplicated cystitis in Korean women. Korean Journal of Urology 2007, 48(1):35-39.

31. Shapiro T, Dalton M, Hammock J, Lavery R, Matjucha J, Salo DF: The prevalence of urinary tract infections and sexually transmitted disease in women with symptoms of a simple urinary tract infection stratified by low colony count criteria. Acad Emerg Med 2005, 12(1):38-44.

32. Andre M, Molstad S, Lundborg CS, Odenholt I, Axelsson I, Eriksson M, et al: Management of urinary tract infections in primary care: A repeated 1week diagnosis-prescribing study in five countries in Sweden in 2000 and 2002. Scandinavian Journal of Infectious Diseases 2004, 36(2):134-138.

33. Jellheden B, Norrby RS, Sandberg T: Symptomatic urinary tract infection in women in primary health care. Bacteriological, clinical and diagnostic aspects in relation to host response to infection. Scand IJ Prim Health Care 1996, 14(2):122-128.

34. Pinkerton RE, Garibaldi RA, Conrad C, Bush F, Brown DH, Testa MA, et al: Urinary tract symptoms: microbiologic evaluation in rural family practice. J Am Board Fam Pract 1988, 1(1):39-45.

35. Butler CC, Hillier S, Roberts Z, Dunstan F, Howard A, Palmer S: Antibioticresistant infections in primary care are symptomatic for longer and increase workload: outcomes for patients with E. coli UTIs. Br J Gen Pract 2006, 56(530):686-692

36. Berg $\mathrm{AO}$, Heidrich FE, Finn SD: Establishing the cause of genitourinary symptoms in women in a family practice. Comparison of clinical examination and comprehensive microbiology. Journal of the American Medical Association 1984, 251(5):620-625.

37. Lawson DH, Clarke A, McFarlane DB, McAllister TA, Linton AL: Urinary tract symptomatology in general practice. J R Coll Gen Pract 1973, 23(133):548-555.

38. Gallagher DJ, Montgomerie JZ, North JD: Acute infections of the urinary tract and the urethral syndrome in general practice. Br Med J 1965, 1(5435):622-626.

39. Dans PE, Klaus B: Dysuria in women. Johns Hopkins Med J 1976, 138(1):13-18.

40. Mond NC, Percival A, Williams JD, Brumfitt W: Presentation, diagnosis, and treatment of urinary-tract infections in general practice. Lancet 1965, 1(7384):514-516.

41. Dobbs FF, Fleming DM: A simple scoring system for evaluating symptoms, history and urine dipstick testing in the diagnosis of urinary tract infection. J R Coll Gen Pract 1987, 37(296):100-104.

42. Baerheim A, Digranes A, Jureen R, Malterud K: Generalized symptoms in adult women with acute uncomplicated lower urinary tract infection: an observational study. MedGenMed 2003, 5(3):1.

43. O'Brien K, Hillier S, Simpson S, Hood K, Butler C: An observational study of empirical antibiotics for adult women with uncomplicated UTI in general practice. J Antimicrob Chemother 2007, 59(6):1200-1203.

44. Berg AO, Heidrich FE, Fihn SD, Bergman JJ, Wood RW, Stamm WE, et al: Establishing the cause of genitourinary symptoms in women in a family practice. Comparison of clinical examination and comprehensive microbiology. JAMA 1984, 251(5):620-625.

45. Foxman B: Epidemiology of urinary tract infections: incidence, morbidity, and economic costs. Am J Med 2002, 113(Suppl 1A):5S-13S.

46. Little P, Moore MV, Turner S, Rumsby K, Warner G, Lowes JA, et al: Effectiveness of five different approaches in management of urinary tract infection: randomised controlled trial. BMJ 2010, 340:c199.

\section{Pre-publication history}

The pre-publication history for this paper can be accessed here: http://www.biomedcentral.com/1471-2296/11/78/prepub

doi:10.1186/1471-2296-11-78

Cite this article as: Giesen et al:: Predicting acute uncomplicated urinary tract infection in women: a systematic review of the diagnostic accuracy of symptoms and signs. BMC Family Practice 2010 11:78.

\section{Submit your next manuscript to BioMed Central and take full advantage of:}

- Convenient online submission

- Thorough peer review

- No space constraints or color figure charges

- Immediate publication on acceptance

- Inclusion in PubMed, CAS, Scopus and Google Scholar

- Research which is freely available for redistribution

Submit your manuscript at www.biomedcentral.com/submit
Biomed Central 